ZOOLOGIA 32(5): 423-427, October 2015

http://dx.doi.org/10.1590/S1984-46702015000500011

\title{
A new species of Sulcana (Hemiptera: Cicadellidae: Gyponini) from the Brazilian Atlantic Forest
}

\author{
Alexandre Cruz Domahovski ${ }^{1}$ \& Rodney Ramiro Cavichioli ${ }^{1}$ \\ ${ }^{1}$ Departamento de Zoologia, Universidade Federal do Paraná. Caixa Postal 19020, 81531-980 Curitiba, PR, Brazil. \\ E-mails: domahovskiac@yahoo.com.br; cavich@ufpr.br
}

\begin{abstract}
Sulcana cunicula sp. nov. is described and illustrated based on four specimens from municipality of São José dos Pinhais, state of Paraná, Brazil. This species can be distinguished from others in the genus by the following characters: (1) head produced, slightly shorter than median length of pronotum; (2) aedeagus bearing a pair of acute ventral processes at mid-length of shaft and extended dorsally. A new record to Sulcana brevis DeLong \& Freytag and a key to the three species of the genus are also presented.
\end{abstract}

KEY WORDS. lassinae; key; leafhoppers; new record; taxonomy.

Sulcana was described by DeLong \& Freytag (1966) and diagnosed as follows: "Elongate, flat-headed leafhoppers with a flattened crown bearing two elongate median carinae, one either side of median line. Crown variable in length, always blunt, rounded. Eyes small, ocelli on basal third of crown. Crown flattened, almost parallel margined on basal half. Face with a broad, deep furrow extending from apex of crown almost half way to the clypeus. Pronotum distinctly shorter than crown. Forewings long and narrow with regular venation." These authors included two species from Mato Grosso State, Brazil: Sulcana brevis DeLong \& Freytag, 1966 (type species) and Sulcana carinata DeLong \& Freytag, 1966. Since that date, no other taxon have been described or new recorded.

In this work, a new species of Sulcana from Brazil, state of Paraná, is described and illustrated. A key to the three known species and a revised diagnosis of the genus are provided.

\section{MATERIAL AND METHODS}

Examined specimens were deposited at the Coleção de Entomologia Pe. Jesus Santiago Moure, Universidade Federal do Paraná, Brazil, Curitiba (DZUP). The terminology follows Young $(1968,1977)$, except for head features (Hamilton 1981, MejDALANi 1998) and leg chaetotaxy with abbreviations (RAKITOV 1997). Techniques for dissection of genitalia follow OMAN (1949), with a few modifications described in Cavichioli \& TAKIYA (2012). Label data are specified between quotation marks, with a backslash $(\backslash)$ separating lines on the labels and a semicolon separating labels attached to the same specimen.

\section{TAXONOMY}

\section{Sulcana DeLong \& Freytag, 1966}

Sulcana DeLong \& Freytag, 1966: 309. Type species: Sulcana brevis DeLong \& Freytag, 1966: 311, by original designation.
Diagnosis. Coloration (Figs. 20-21): pale brown. Body elongated. Head and thorax (Figs. 1, 3) with several deep and minute pits. Crown variable in length, more than half as long as interocular width, bearing two longitudinal carinae, one on each side of median line; anterior margin foliaceous. Ocelli (Fig. 1) located before an imaginary line between anterior eye angles, each closer to median line of crown than adjacent to anterior eye angle and laterally in the longitudinal carinae. Front (Fig. 2) with deep median groove extending from apex of crown to approximately one-third of front. Genae with lateral margins sinuous. Hindleg with femoral setal formula $2: 2: 1: 1$ or $2: 2: 1$; tibiae row $\mathrm{AD}$ with three slender intercalary setae between cucullate setae. Forewing (Fig. 4) long and narrow, lacking extra numerary veins and appendix reduced. Subgenital plate (Fig. 7) with acute apex and slightly turned upward. Style (Fig. 8) with deep notch in basal third on external margin, in dorsal view. Aedeagus (Figs. 11-12) with preatrium slightly produced; dorsal apodemes short and well divergent, almost T-shaped; lacking atrial processes.

Remarks. The median length of the crown shows great variation among the currently recognized species of Sulcana. For instance, it may be longer than the median length of the pronotum in S. carinata, approximately as long as in S. brevis, or slightly shorter in $S$. cunicula sp. nov. The lateral margins of the crown are almost parallel at the base in S. carinata. In other species, the lateral margins converge towards the apex of the crown. The examined specimens of $S$. brevis have femoral setal formula 2:2:1 with slight size variation in the setae between right and left femora, especially the $\mathrm{AD}_{2}$ setae. Variation in femoral setal formula was previously observed by ENGEL \& TAKIYA (2012) in specimens of Clinonana mirabilis (Spångberg, 1878). Species of Sulcana superficially resemble those of Sordana Delong, 1976 (three species with widespread distribution in South America) due to the presence of several dark minute pits at head and thorax; L-shaped style with hook-shaped apex, curved dorsally; subgenital plate with acute apex; and aedeagus lacking atrial processes. However,

2015 | Sociedade Brasileira de Zoologia | www.sbzoologia.org.br | www.scielo.br/zool All content of the journal, except where identified, is licensed under a Creative Commons attribution-type BY. 
representatives of Sulcana can be differentiated by the greater median length of the crown, two longitudinal carina on each side of the median line and deeper pits at head and thorax. Sordana has a single rounded elevation on the crown, between the ocelli and the median line, like a callus, with the ocelli located in the lateral margin of the sloping portion of the callus.

\section{Species of Sulcana}

Sulcana brevis DeLong \& Freytag, 1966: 311. Brazil: Mato Grosso and Minas Gerais (new record).

Sulcana carinata DeLong \& Freytag, 1966: 309. Brazil: Mato Grosso. Sulcana cunicula sp. nov. Brazil: Paraná.

\section{Sulcana brevis DeLong \& Freytag, 1966}

Material examined. 1 male, "Brasil, Mato Grosso, \Chapada 12.xi.2013 light $\backslash$ trap G. Melo leg.", 1 male "Brasil, Minas Gerais, $10 \backslash \mathrm{Km}$ a SE de Berizal. Faz [Fazenda] \Veredão $15^{\circ} 40^{\prime} \mathrm{S} \backslash 41^{\circ} 40^{\prime} \mathrm{W}$ 850m \13.ii.2010 G. Melo, \D. Parizotto \& P. Grossi \arm. [armadilha] luminosa (18-20h)"

Remarks. This species was described from state of Mato Grosso, Brazil and herein firstly recorder from state of Minas Gerais, Brazil.

\section{Sulcana cunicula sp. nov.}

Figs. 1-21

Diagnosis. Head (Fig. 1) produced, median length approximately six-tenths interocular width, slightly shorter than median length of pronotum. Aedeagus (Figs. 11-12) bearing a pair of acute ventral processes at mid-length of shaft and extended dorsally.

Measurements. Length $7.60 \mathrm{~mm}$ (holotype), female (paratype) $8.96 \mathrm{~mm}$.

Description. Crown (Fig. 1) produced in dorsal view, median length approximately six-tenths interocular width; ocelli closer to median line than to eyes, nearer posterior margin of crown; clypeus slightly inflated in lateral view, base as wide as apex in frontal view (Fig. 2); anterior margin foliaceous in lateral view, lacking transverse striae (Fig. 3). Pronotum (Fig. 3) slightly declivous in lateral view, with transverse striae indistinct. Forewing (Fig. 4) approximately three times longer than wide, lacking extra numerary cross veins, with R1 vein, and three closed anteapical cells. Prothoracic femora with AD, $\mathrm{AM}$ and $\mathrm{PD}$ rows reduced, except for apical setae $\mathrm{AD}_{1}, \mathrm{AM}_{1}$ and $\mathrm{PD}_{1}$; rows $\mathrm{AV}$ and $\mathrm{PV}$ showing three sparse setae, distributed from base to apex; IC row formed by comb of fine setae, slightly arched, extended from distal half of femur to $\mathrm{AM}_{1}$. Hindleg with femoral setal formula 2:2:1.

Coloration. Head and thorax (Figs. 1-3) pale brown with darker spots. Forewings (Fig. 4) translucent light brown, veins outlined with dark brown and black spots; inner margin and appendix dark brown.

Male terminalia. Sternite VIII (Fig. 5) approximately two times wider than long; posterolateral corners rounded, poste- rior margin with median portion slightly produced with a shallow V-shaped notch. Pygofer (Fig. 6) 1.6 times longer than its maximum height; posteroventral and posterodorsal margins converging towards round apex; apical half covered with macrosetae; valve approximately two times as wide as long; posterior margin straight. Subgenital plate (Fig. 6) in lateral view reaching apex of pygofer; apex dorsally curved; in ventral view (Fig. 7) approximately 4.5 times as long as wide, tapered and acute. Connective (Figs. 8-9) Y-shaped, stalk apex oriented ventrally; rami longer than stalk. Style L-shaped; in dorsal view (Fig. 8), with conspicuous truncate outer lobe; in lateral view (Fig. 10), blade slightly tapered towards the apex; ventral margin not serrated; apex hookshaped, dorsally curved. Aedeagus (Figs. 11-12) with dorsal apodeme broad in posterior view, shaft slightly curved anteriorly, lacking apical processes and bearing a pair of acute ventral processes at mid-length of shaft and extended dorsally.

Female terminalia. Sternite VII (Fig. 13) 1.5 times wider than its median length; posterolateral angles rounded and slightly produced; posterior margin slightly more produced than lateral angles, with V-shaped notch at center. Internal sternite VIII (Figs. 14-15) sclerotized, dorsal surface sculptured in a brainlike pattern, lateral angles rounded basally. Pygofer (Fig. 15) short, 1.2 times longer than maximum height; apex rounded; macrosetae present on posterior two-thirds. First valvifer (Fig. 16) approximately as high as long, dorsal margin straight. First valvulae (Fig. 16) approximately rectilinear, 7.5 times longer than maximum height; apical half with dorsal area sculptured and strigate; apex (Fig. 17) narrow with dorsoapical margin straight, and ventroapical margin slightly convex. Second valvulae (Fig. 18) higher on median $3 / 5$; apical third with dorsal margin finely serrated; apex (Fig. 19) triangular, with irregular shaped teeth.

Material examined. Holotype, male: “Brasil, Paraná, S. [São] J. [José] dos $\backslash$ Pinhais $25^{\circ} 36^{\prime} 11.0^{\prime \prime} \backslash \backslash 49^{\circ} 11^{\prime} 32.5^{\prime \prime} \mathrm{W} 883 \mathrm{~m} \backslash 12$. ii. 2012 Sweep $\backslash$ A. C. Domahovski leg.". Paratypes: 1 male, "Brasil, São José \dos Pinhais Malaise-3 $\backslash 25^{\circ} 36^{\prime} 01.40^{\prime \prime} S \backslash 49^{\circ} 11^{\prime} 24.66^{\prime \prime} \mathrm{W} 880 \mathrm{~m} \backslash$ 19-26.IX.2015 \A. C. Domahovski leg."; 1 female, same holotype data except 20.ii.2012; 1 female, "Curitiba PR \Brasil II.1984\ Cavichioli Leg" [DZUP].

Etymology. The specific name, cunicula, comes from the Latin "cuniculus", which means rabbit. It refers to the processes of the aedeagal shaft, which resembles rabbit ears.

Remarks. Sulcana cunicula sp. nov. can be easily distinguished from other Sulcana species by the shape of the aedeagal shaft with ventral processes at mid-length. This species is similar to $S$. brevis due to the smaller length of the crown.

\section{Key to species of Sulcana (males)}

1. Median length of crown (Fig. 1) slightly shorter than median length of pronotum; aedeagal shaft (Fig. 11) with ventral processes at mid-length of shaft; apex of shaft lacking processes .................... S. cunicula sp. nov. (Brazil, Paraná)

$1^{\prime}$. Median length of crown as long or slightly longer than median length of pronotum; shaft lacking median process; 

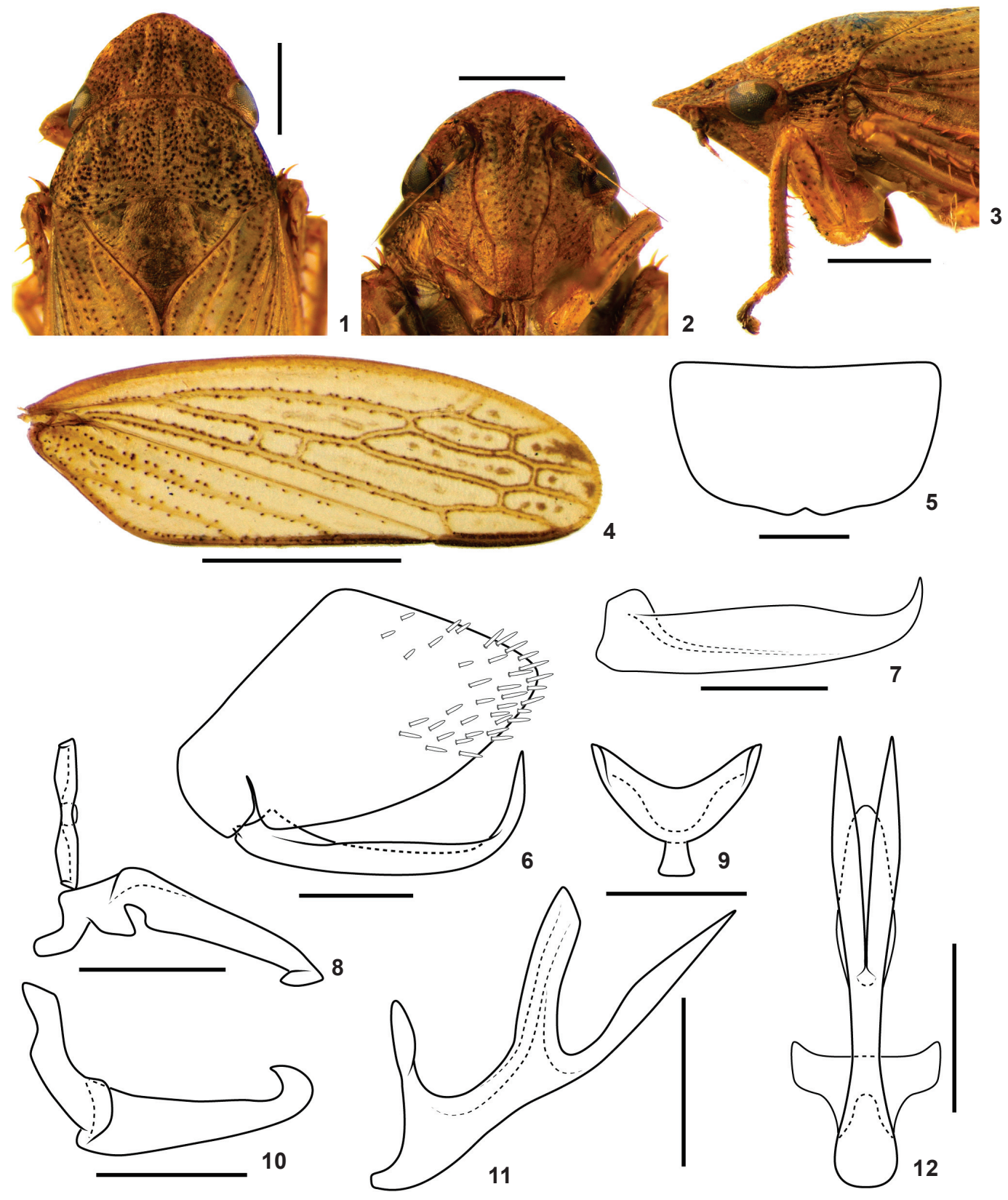

Figures 1-12. Sulcana cunicula sp. nov., holotype male: (1) head and thorax, dorsal view; (2) head, frontal view; (3) head and thorax, lateral view; (4) forewing, dorsal view; (5) sternite VIII, ventral view; (6) pygofer and subgenital plate, lateral view; (7) subgenital plate, ventral view; (8) style and connective, dorsal view; (9) connective, posterior view; (10) style, lateral view; (11) aedeagus, lateral view; (12) aedeagus, posterior view. Scale bars: $1-3=1.0 \mathrm{~mm}, 4=2.0 \mathrm{~mm}, 5-12=0.5 \mathrm{~mm}$.

shaft with apical or subapical processes .. 2

2. Median length of crown as long as median length of pronotum; aedeagal shaft with two pairs of processes, one pair preapical returned anteriorly and other apical directed posteriorly
S. brevis (Brazil, Mato Grosso and Minas Gerais)

2 ' Median length of crown slightly longer than median length of pronotum; aedeagal shaft with two pairs of apical processes directed posteriorly

S. carinata (Brazil, Mato Grosso) 


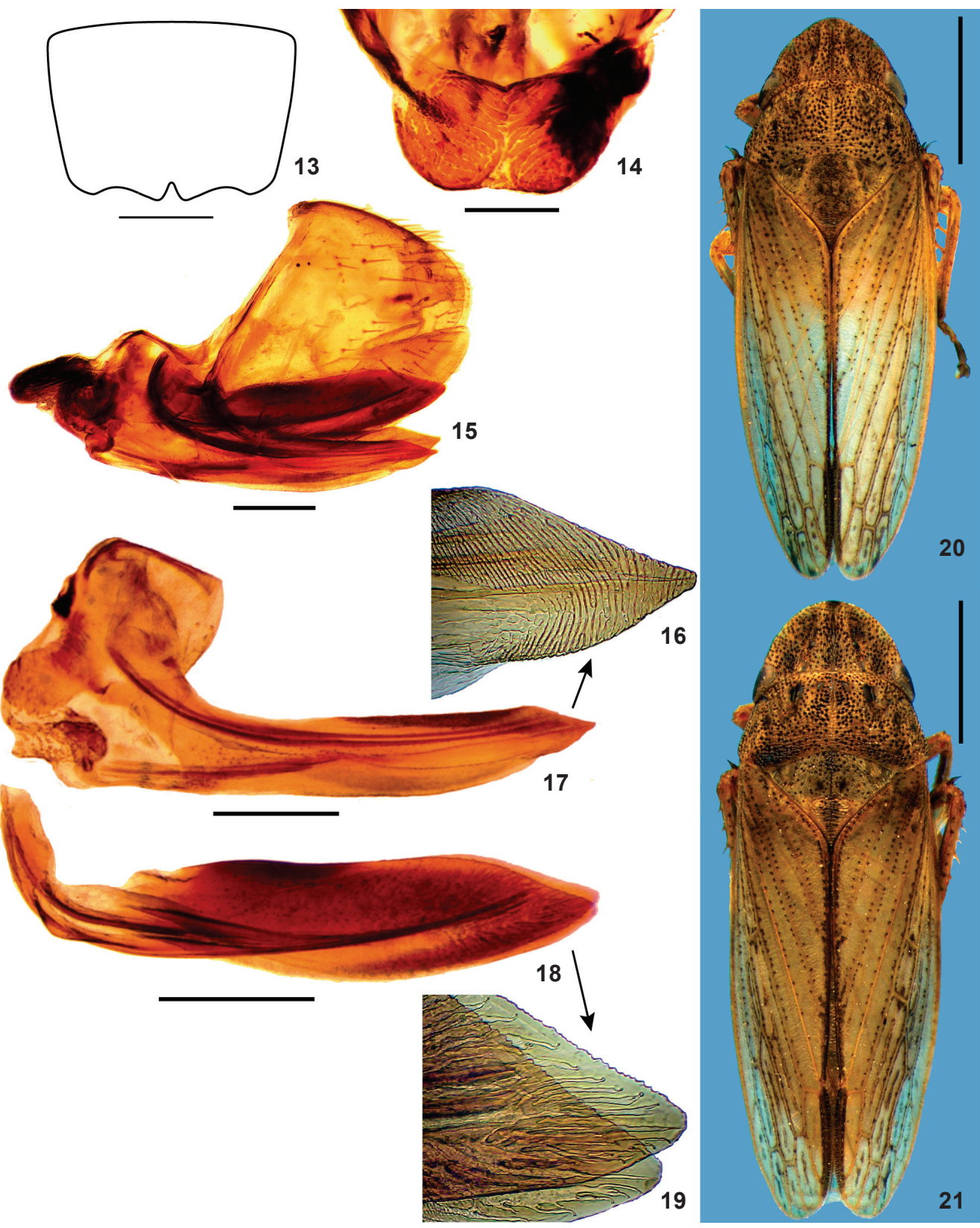

Figures 13-21. Sulcana cunicula sp. nov.: (12-19) paratype, female terminalia: (13) sternite VII, ventral view; (14) internal sternite VIII, dorsal view; (15) pygofer and ovipositor, lateral view; (16) first valvulae, lateral view; (17) first valvulae, apical portion; (18) second valvulae, lateral view; (19) second valvulae, apical portion. (20-21) habitus: (20) holotype male, dorsal view; (21) paratype female, dorsal view. Scale bars: 13-15, 16-18 $=0.5 \mathrm{~mm}, 20-21=2.0 \mathrm{~mm}$.

\section{ACKNOWLEDGEMENTS}

We thank Olivia Evangelista de Souza and Keith Bayless for corrections and revisions of the English of this paper; and two anonymous reviewers for providing comments and cor- rections on an earlier draft of this paper. This work was supported by grants from CNPq (ACD, process $130388 / 2015-7$, and RRC, process 305484/2014-1). This paper is the contribution number 1927 of the Departamento de Zoologia, Universidade Federal do Paraná. 


\section{LITERATURE CITED}

Cavichioli RR, TakiYa DM (2012) Description of a new species of Wolfniana and new records of Rotigonalia (Hemiptera: Cicadellidae: Cicadellinae) from the state of Amazonas, Brazil. Zoologia 29(1): 85-88. doi: 10.1590/S1984-46702012000100011

Delong DM, Freytag PH (1966) Studies of the Gyponinae: Two new primitive genera - Coelogypona and Sulcana (Homoptera: Cicadellidae). Proceedings of the Entomological Society of Washington 68(4): 309-313.

Engel G, Takiya DM (2012) Synopsis of Clinonana Osborn (Hemiptera: Cicadellidae: Iassinae): new distributional records and description of a new species. Zootaxa 3329: 19-30.

Hamilton KGA (1981) Morphology and evolution of the rhynchotan head (Insecta: Hemiptera, Homoptera). Canadian Entomologist 113: 953-974. doi: 10.4039/ Ent113953-11

Mejdalani G (1998) Morfologia externa dos Cicadellinae
(Homoptera, Cicadellidae): comparação entre Versigonalia ruficauda (Walker) (Cicadellini) e Tretogonia cribrata Melichar (Proconiini), com notas sobre outras espécies e análise da terminologia. Revista Brasileira de Zoologia 15(2): 451544. doi: 10.1590/S0101-81751998000200015

OMAn PW (1949) The Nearctic leafhoppers (Homoptera: Cicadellidae). A generic classification and check list. Memoirs of the Entomological Society of Washington 3: 1-253.

RAKITOv RA (1997) On differentiation of cicadellid leg chaetotaxy (Homoptera: Auchenorrhyncha: Membracoidea). Russian Entomological Journal 6: 7-27.

Young DA (1968) Taxonomic study of the Cicadellinae (Homoptera: Cicadellidae), Part 1, Proconiini. Bulletin of the United States National Museum 261: 1-287.

Young DA (1977) Taxonomic study of the Cicadellinae (Homoptera: Cicadellidae), Part 2, New World Cicadellini and the genus Cicadella. Technical Bulletin of the North Carolina Agricultural Experiment Station 239: 1-1135.

Submitted: 25 June 2015

Received in revised form: 1 September 2015

Accepted: 21 September 2015

Editorial responsibility: Ângelo Parise Pinto 